Original article

\title{
Seasonal and inter-annual variability of bacterioplankton biomass at station Kerfix, off Kerguelen Islands, Antarctica
}

\author{
Variabilité saisonnière et interannuelle de la biomasse \\ bactérioplanctonique à la station Kerfix (îles Kerguelen, \\ océan Antarctique)
}

\author{
Daniel Delille * \\ Laboratoire Arago, Université P. \& M. Curie, UMR-CNRS 7621, 66650 Banyuls-sur-mer, France
}

Received 27 November 2002; revised and accepted 5 February 2003

\begin{abstract}
Between January 1992 and March 1995, the research project Kerfix undertook the first regular non-coastal multiyear acquisition of parameters related to the carbon cycle in the Southern Ocean at a time series station located at $50^{\circ} 40^{\prime} \mathrm{S}-68^{\circ} 25^{\prime} \mathrm{E}$, $110 \mathrm{~km}$ southwest of the Kerguelen Islands. I present here a general overview of the bacteriological data collected during this survey. Bacterioplankton biomass at Kerfix station was always significantly lower than in the direct vicinity of the Kerguelen Islands. Bacterial abundance decreased from surface to deepest layers (from $10^{6}$ cells ml ${ }^{-1}$ in surface layer to $5.0 \times 10^{4}$ cells ml ${ }^{-1}$ at $1500 \mathrm{~m}$ ). In contrast, mean cell volume $\left(0.1 \mu \mathrm{m}^{3}\right)$ and proportion of free-living bacteria (80\%) were relatively constant through the entire water column. The results suggest that a relatively low seasonal and inter-annual variability affect the total bacterial abundance, the mean cell volume and the percentage of free-living cells. The bacterial biomass is at least equivalent to that of phytoplankton in the surface layers. If integrated over the whole water column it reaches values higher than $1 \mathrm{~g}$ $\mathrm{C} \mathrm{m}^{-2}$, which are higher than the corresponding values of phototrophic biomass.
\end{abstract}

(C) 2003 Éditions scientifiques et médicales Elsevier SAS and Ifremer/CNRS/IRD. All rights reserved.

\section{Résumé}

Le premier programme d'acquisition régulière de données relative au cycle du carbone mené dans l'océan Antarctique s'est déroulé entre janvier 1992 et mars 1995 dans le cadre de l'opération Kerfix. Cette station est située par 5040’ S et 68²5'E, à $110 \mathrm{~km}$ au sud-ouest des îles Kerguelen. Le présent article a pour but de présenter les données bactériologiques collectées durant ce suivi pluriannuel. Les valeurs de biomasse bactérienne observées sur la station Kerfix sont toujours très largement inférieures à leurs équivalents mesurés dans la zone côtière des îles Kerguelen. L'abondance bactérienne décroît de la surface vers le fond (de $10^{6}$ cellules $\mathrm{ml}^{-1}$ en surface à $5.0 \times 10^{4}$ cellules $\mathrm{ml}^{-1}$ à $1500 \mathrm{~m})$. En revanche le volume cellulaire moyen $\left(0,1 \mu^{3}\right)$ et la proportion de bactéries libres $(80 \%)$ restent relativement constants sur l'ensemble de la colonne d'eau. Les résultats suggèrent que les trois paramètres bactériens mesurés ne sont que relativement peu affectés par les variations saisonnières et pluriannuelles constatées sur les autres paramètres du suivi (phytoplancton, nutriments organiques et minéraux). Alors qu'en surface, la biomasse bactérienne est voisine de celle du phytoplancton, si elle est intégrée sur l'ensemble de la colonne d'eau, elle atteint des valeurs supérieures à $1 \mathrm{~g} \mathrm{C} \mathrm{m}^{-2}$ qui sont très largement supérieures aux valeurs correspondantes de la biomasse phototrophe. (C) 2003 Éditions scientifiques et médicales Elsevier SAS and Ifremer/CNRS/IRD. All rights reserved.

Keywords: Antarctic ocean; Bacterial biomass; Vertical distribution; Seasonal changes; Interannual variability

Mots clés : Océan Antarctique ; Biomasse bactérienne; Distribution verticale ; Variations saisonnières ; Variabilité interannuelle

* Corresponding author.

E-mail address: daniel.delille@ wanadoo.fr (D. Delille). 


\section{Introduction}

Since the oceans may be an important sink for the rapidly increasing concentration of anthropogenic $\mathrm{CO}_{2}$, a central objective of major biological oceanographic programs is to quantify, model and predict, at global and annual scales, the flux of biogenic carbon to deep waters (Trembley et al., 1997). Most of the biological studies conducted off shipboard in the Southern Ocean were focused on regional variability aspects. The seasonal variability in plankton biomass is poorly documented due to scarcity of time series observations conducted over one or several years (Horne et al., 1969; Whitaker, 1982; Delille, 1990; Helbling et al., 1995; Moline and Prézelin, 1996). However, seasonal changes have to be understood if accurate carbon budgets are to be constructed (Platt et al., 1992; Priddle et al., 1992; Tréguer and Jacques, 1992). This is particularly true for the Austral Ocean with intense temporal variability, perhaps the most extreme seasonality observed any where in the world ocean (Karl, 1993).

Furthermore the majority of the available long-term planktonic studies in the Antarctic zone are focused on phytoplankton. Few investigators have examined both bacteria and phytoplankton over an annual cycle (Gibson et al., 1990; Rivkin, 1991; Leakey et al., 1994; Delille et al., 1996). From 1990 to 1994, the research program Kerfix (as part of the French contribution to JGOFS) proposed a time-series station located in the Indian sector of the Southern Ocean, south-west off the Kerguelen Islands. The main objectives of this project were to monitor the ocean/atmosphere $\mathrm{CO}_{2}$ fluxes and to understand the seasonal variability of associated elements at this location (Jeandel et al., 1998; Louanchi et al., 2001). Previous papers presented phytoplankton biomass and taxonomic composition data obtained during this survey (Fiala et al., 1998; Kopczynska et al., 1998). The purpose of the present paper is to document, for the first time in the northern part of the Southern Ocean, the seasonal and inter-annual changes in the biomass and abundance of the total bacterioplankton present in the water column at station Kerfix.

\section{Materials and methods}

Kerfix station is located in the Southern Ocean, $110 \mathrm{~km}$ south-west off Kerguelen Islands (5040'S, 68 25'E, Fig. 1 in the North of the Permanently Open Ocean Zone (Pooz). Detailed description of hydrographic and biogeochemical data collected at station Kerfix together with their sampling methods, validation, and precision are given in Jeandel et al. (1998). Samples were collected monthly aboard the coastal oceanographic ship "La Curieuse" using Niskin bottles, for three years, from January 1992 to March 1995. Biological samples were collected at 23 depths in the entire water column (from 0 to $1500 \mathrm{~m}$ ). The nominal bottle depths were $0,10,20,30,50,75,100,150,200,250$ and $300 \mathrm{~m}$, and then every $100 \mathrm{~m}$ down to $1500 \mathrm{~m}$.

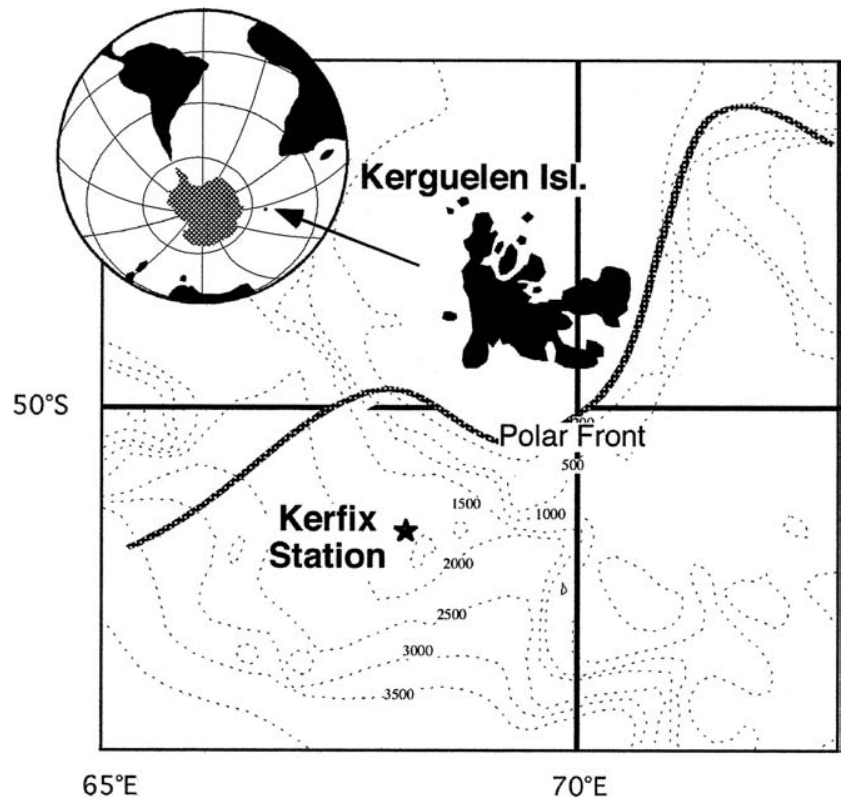

Fig. 1. Location of the time-series station Kerfix (50 $\left.40^{\circ} \mathrm{S}-68^{\circ} 25^{\prime} \mathrm{E}\right), 110$ $\mathrm{km}$ south-west off Kerguelen Islands. The mean position of the Polar Front (PF) is indicated according to Park et al. (1998).

Total bacterial counts were determined with formalin preserved samples by acridine orange direct count with an Olympus epifluorescence microscope according to the method of Hobbie et al. (1977). A minimum of 300 fluorescing cells with a clear outline and definite cell shape were counted as bacterial cells on $0.22 \mu \mathrm{m}$ pore-size Nuclepore filters in a minimum of 10 randomly selected microscope fields. Free living and particle related bacteria were counted separately.

Cell volumes were estimated using an ocular micrometer. Cells were divided into two classes for calculation of bacterial volumes: spheres and rods (cylinders with hemispheres at each end).

Bacterial biomass was calculated using two different methods, an average bacterial cell mass of $60 \mathrm{fg} \mathrm{C}^{\mathrm{C}} \mathrm{cell}^{-1}$ (Bjørnsen, 1986; Trousselier et al., 1997) was applied to total cell numbers and secondly, a volume specific conversion

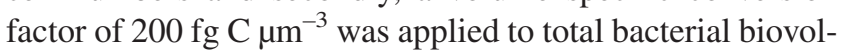
ume (Bjørnsen and Kuparinen, 1991; Theil-Nielsen and Søndergaard, 1998).

\section{Results}

Vertical distribution of total bacterial abundances observed in 1994-1995 is presented as time-depth diagram in Fig. 2. Oceanic seasons of the site are defined as following: spring is from November to January; summer is from February to April; autumn is May to July; and winter is from August to October. Bacterial abundances can reach values higher than $10^{6}$ cells $\mathrm{ml}^{-1}$ in surface layer during winter (October 1994). A clear decreasing gradient of bacterial abundance is generally observed in the upper part of the water column. Bacterial counts can reach values as low as 


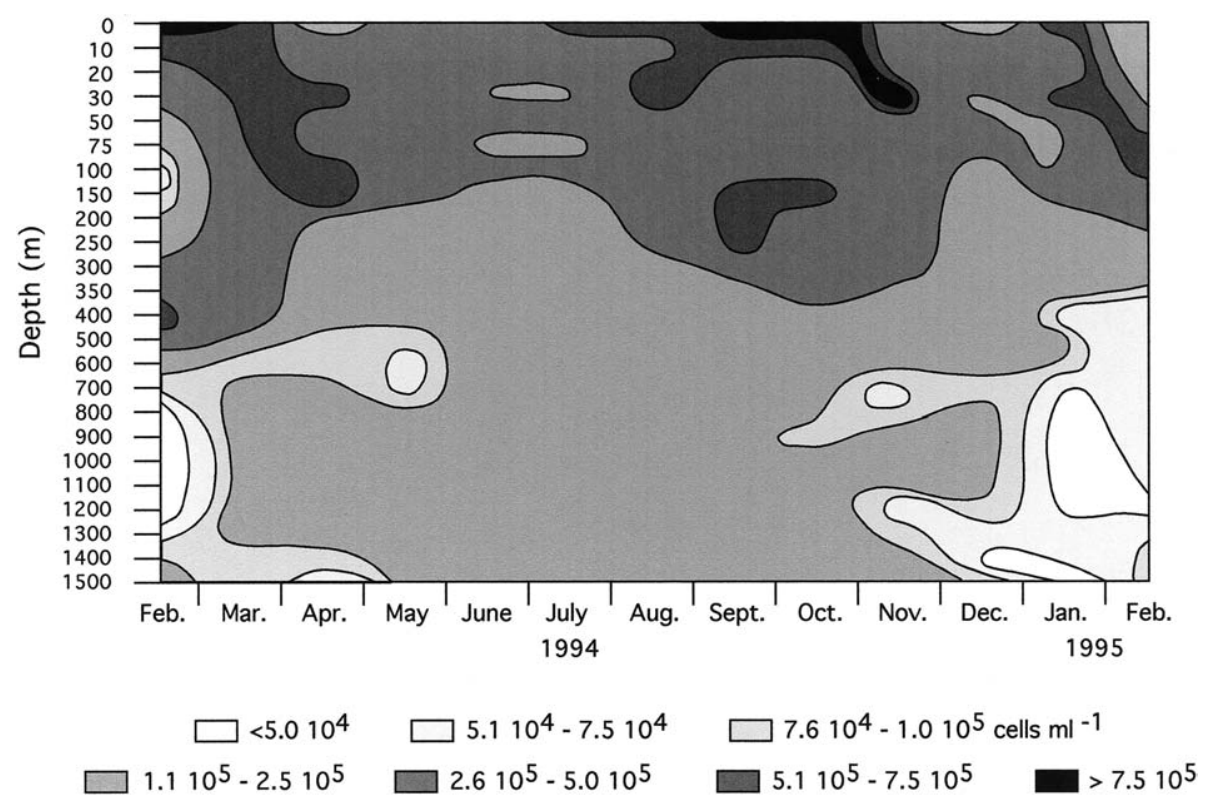

Fig. 2. Seasonal changes at Kerfix station in depth distribution of total bacterial abundances from February 1994 to 1995.

$10^{4}$ (1100 $\mathrm{m}$ in February 1994) in the deeper part of the water column. However, relatively linear vertical profiles were observed under $300 \mathrm{~m}$ in wintertime. Bacterial abundances were relatively constant during the year in the upper part of the water column. In contrast a clear seasonality, with higher

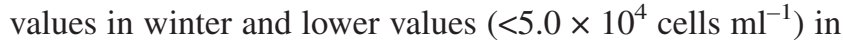
summer, occurred in the deepest part of the water column. Vertical distributions of mean cell volumes show strong variations Fig. 3. Highest cell volumes were generally observed in sub-surface layers during spring or summer. However, sub-surface maxima were frequently observed $\left(0.3 \mu \mathrm{m}^{3}\right.$ in February, July and December). A surprising increasing gradient with increasing depth was observed in November. However, on an annual basis, mean cell volume appeared as relatively constant Fig. 4 .
The percentage of free-living bacteria showed only little vertical, seasonal and inter-annual variability (between $75 \%$ and $80 \%$, data not shown).

Relatively little inter-annual variability of mean cell volume was observed Fig. 4. In contrast, some inter-annual trends were recorded in bacterial abundance. In the deepest part of the water column (below $600 \mathrm{~m}$ ) the recorded bacterial abundance were lower in 1993 than in 1992 and 1994.

\section{Discussion}

A relatively high fraction of non-active cells and ghosts has recently been reported for seawater (Zweifel and Hagström, 1995; Gazol et al., 1995; Lovejoy et al., 1996). Thus,

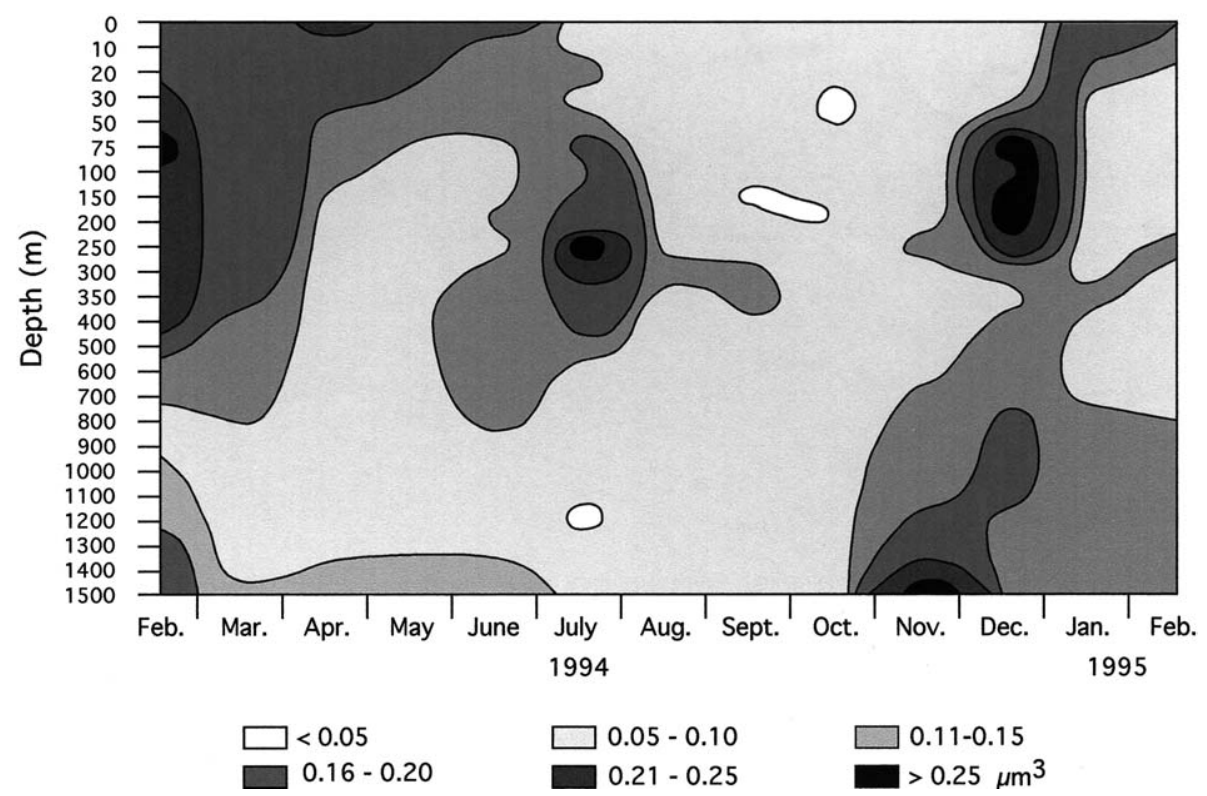

Fig. 3. Seasonal changes at Kerfix station in depth distribution of mean cell volumes from February 1994 to 1995. 


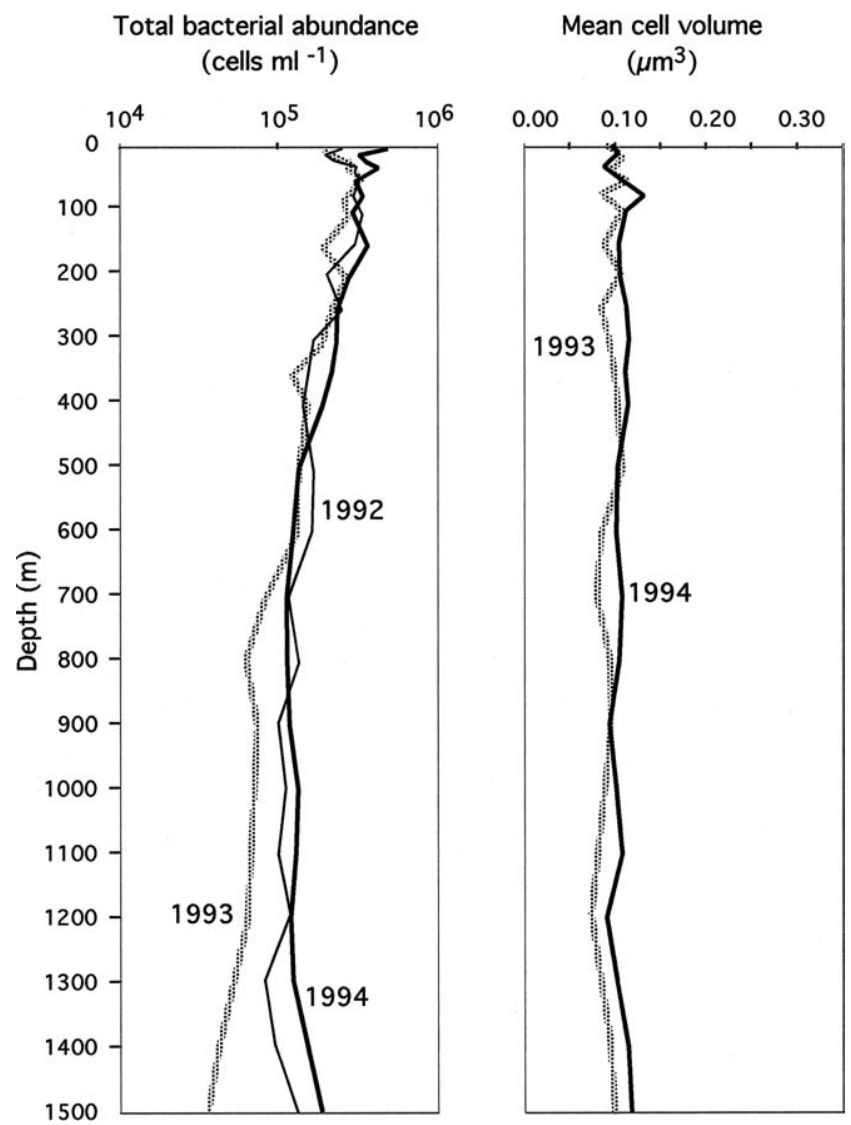

Fig. 4. Inter-annual variability of vertical distribution of bacterial abundances and mean cell volumes (annual mean).

as previously suggested in the same area (Delille, 1990), the observed bacterial abundance does not necessarily reflect the bacterial activity. In any case the observed changes are too large (two orders of magnitude) to be related uniquely to fluctuation of the proportion of active and inactive cells.

The marked seasonality of bacterial parameters observed in the Kerguelen coastal area (Morbihan Bay, Delille, 1990) is strongly reduced in this more oceanic area. Subantarctic bacterial biomass recorded during bacterial blooms in the Kerguelen coastal area are among the highest ever recorded (Delille et al., 1996). The present data were always smaller during this more offshore study. However, they remain relatively high when compared with field data that are available for Antarctic Ocean (Hodson et al., 1981; Cota et al., 1990; Goeyens et al., 1991; Delille, 1992). They are consistent when compared to some values reported for Bransfield Strait

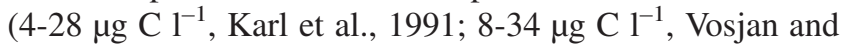
Olanczuk-Neyman, 1991), southern Antarctic Pacific zone (9-82 $\mu \mathrm{g} \mathrm{C}^{-1}$, Sazhin, 1993) and Terre Adélie coastal area (1-30 $\mu \mathrm{g} \mathrm{C}^{-1}$, Delille, 1993).

In studies of carbon dynamics in aquatic microbial communities, the ability to convert bacterial abundance or bacterial biovolume to carbon is crucial in order to calculate bacterial biomass. Considering variability due to differences in bacterial species composition and bacterial growth conditions it is not surprising to observe a wide spectrum of conversion factors. One of most commonly used factor for

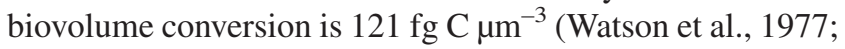
Theil-Nielsen and Søndergaard, 1998). However, in the Southern Ocean Bjørnsen and Kuparinen (1991) found a

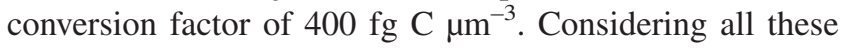
available data the extreme values for the biovolume conver-

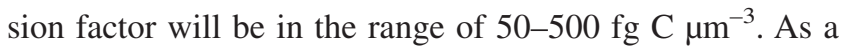
consequence of the low correlation between carbon per cell and cell volume, a constant cell mass would seem to be a logical choice for bacterial biomass estimation (Trousselier et al., 1997). Cell mass is, however, also subject to controversy. If, for some specific species, cell mass is quite constant during cell volume decreases associated with starvation (Trousselier et al., 1997), for an assemblage of different species cell mass will remain dependent on cell volume (Gazol et al., 1995; Theil-Nielsen and Søndergaard, 1998). Considering all available observations, the extreme values of bacterial cell mass will be in the range of 20-120 $\mathrm{fg} \mathrm{C}^{-1}{ }^{-1}$.

Results obtained by the two calculation modes are slightly different. Lowest values are of the same order of magnitude but the highest values are higher with the cell number calculation than with the cell volume one. The differences will be related with the discrepancy between bacterial abundance and cell volume. Largest cells are not necessarily observed during the maximal abundance periods. However, the data obtained by the two calculation modes agree relatively well. In any case, using the smallest values obtained, the integrated bacterial biomass in the upper $100 \mathrm{~m}$ will be higher than $200 \mathrm{mg} \mathrm{C} \mathrm{m}^{-2}$. This value is of same order of magnitude than the phytoplankton biomass $\left(38.8-852.1 \mathrm{mg} \mathrm{C} \mathrm{m}^{-2}\right.$, with a mean value of $225.3 \mathrm{mg} \mathrm{C} \mathrm{m}^{-2}$, Fiala et al., 1998). Thus the bacterial biomass will at least be equivalent to that of phytoplankton in the surface layers. If integrated over the whole water column, bacterial biomass will reach values higher than $1 \mathrm{~g} \mathrm{C} \mathrm{m}^{-2}$, which is obviously higher than the autotrophic biomass. Estimates of phytoplankton primary production to community respiration ratios suggest that many parts of the ocean margins show a net heterotrophic activity in all but the coldest season (Smith and Mackenzie, 1987). Seasonal changes in growth rates and respiratory demands of aerobic heterotrophic bacteria, which dominate total community respiration, can induce changes from heterotrophy to autotrophy (Hopkinson, 1985; Griffith et al., 1990; Wiebe et al., 1993). Thus such "inverted pyramid" where heterotrophs exceed autotrophs is not surprising (see Gazol et al., 1997, for a review) and will be an indication of the oligotrophic characteristics of this part of the Southern Ocean.

\section{Acknowledgements}

This work was supported by CNRS-INSU (JGOFS-France program) and Ipev (French Polar Institute). I thank P. Guyot, G. Du Réau and J. Maison who collected samples during the 3 successive years of the study. 


\section{References}

Bjørnsen, P.K., 1986. Automatic determination of bacterioplankton biomass by image analysis. Appl. Environ. Microbiol 51, 1199-1204.

Bjørnsen, P.K., Kuparinen, J., 1991. Determination of bacterioplankton biomass, net production and growth efficiency in the Southern Ocean. Mar. Ecol. Prog. Ser 71, 185-194.

Cota, G.F., Kottmeier, S.T., Robinson, D.H., Smith Jr, W.O., Sullivan, C.W., 1990. Bacterioplankton in the marginal ice zone of the Weddell Sea: biomass, production and metabolic activities during austral autumn. Deep-Sea Res 37, 1145-1167.

Delille, D., 1990. Seasonal changes of subantarctic heterotrophic bacterioplankton. Arch. Hydrobiol 119, 267-277.

Delille, D., 1992. Marine bacterioplankton at the Weddell Sea ice edge: distribution of psychrophilic and psychrotrophic populations. Polar Biol 12, 205-210.

Delille, D., 1993. Seasonal changes in the abundance and composition of marine bacterial communities in an Antarctic coastal area. Polar Biol 13, 463-470.

Delille, D., Fiala, M., Razouls, S., 1996. Seasonal changes in bacterial and phytoplankton biomass in a subantarctic coastal area (Kerguelen Islands). Hydrobiologia 330, 143-150.

Fiala, M., Kopczynska, E.E., Jeandel, K., Oriol, L., Vetion, G., 1998. Seasonal and interannual variability of size-fractionated phytoplankton biomass and community structure at station Kerfix, off the Kerguelen Islands, Antarctica. J. Plankton Res 20, 1341-1356.

Gazol, J.M., Del Giorgio, P.A., Massana, R., Duarte, C.M., 1995. Active versus inactive bacteria: size-dependence in a coastal marine plankton community. Mar. Ecol. Prog. Ser 128, 91-97.

Gazol, J.M., Del Giorgio, P.A., Duarte, C.M., 1997. Biomass distribution in marine planktonic communities. Limnol. Oceanogr 42, 1353-1363.

Gibson, J.A.E., Garrick, R.C., Burton, H.R., 1990. Seasonal fluctuation of bacterial numbers near the Antarctic continent. Polar Biol 3, 16-22.

Goeyens, L., Tréguer, P., Lancelot, C., Mathot, S., Becquevort, S., Morvan, J., Dehairs, F., Baeyens, W., 1991. Ammonium regeneration in the Scotia-Weddell confluence area during spring 1988. Mar. Ecol. Prog. Ser 78, 241-252.

Griffith, P.C., Douglas, D.J., Wainright, S.C., 1990. Metabolic activity of size-fractionated microbial plankton in estuarine, nearshore, and continental shelf waters of Georgia. Mar. Ecol. Prog. Ser 59, 263-270.

Helbling, E.W., Villafañe, V.E., Holm-Hansen, O., 1995. Variability of phytoplankton distribution and primary production around Elephant Island, Antarctica, during 1990-1993. Polar Biol 15, 233-246.

Hobbie, J.E., Daley, R.J., Jasper, S., 1977. Use of nuclepore filters for counting bacteria by fluorescence microscopy. Appl. Environ. Microbiol $33,1225-1228$.

Hodson, R.E., Azam, F., Carlucci, A.F., Fuhrman, J.A., Karl, D.M., HolmHansen, O., 1981. Microbial uptake of dissolved organic matter in McMurdo Sound, Antarctica. Mar. Biol 61, 89-94.

Hopkinson, C.S., 1985. Shallow-water benthic and pelagic metabolism: evidence of heterotrophy in the nearshore Georgia Bight. Mar. Biol 87, $19-32$

Horne, A.J., Fogg, G.E., Eagle, D.J., 1969. Studies in situ of the primary production of an area of inshore Antarctic Sea. J. Mar. Biol. Ass. UK 49, 393-405.

Jeandel, C., Ruiz-Pino, D., Gatja, E., Poisson, A., Brunet, C., Charriaud, E., Dehairs, F., Delille, D., Fiala, M., Fravalo, C., Miquel, J.C., Park, Y.H., Razouls, S., Quéguiner, B., Shauer, B., Tréguer, P., 1998. Kerfix a permanent time series station in the Southern Ocean: a presentation. J. Mar. Syst 17, 555-569.

Karl, D.M., 1993. Microbial processes in the southern oceans. In: Friedmann, E.I. (Ed.), Antarctic Microbiology. Wiley-Liss, Inc., New York, pp. 1-63.
Karl, D.M., Holm-Hansen, O., Taylor, G.T., Tien, G., Bird, D.F., 1991. Microbial biomass and productivity in the western Bransfield Strait, Antarctica during the 1986-87 summer. Deep-Sea Res 89, 1029-1055.

Kopczynska, E.E., Fiala, M., Jeandel, C., 1998. Annual and interannual variability in phytoplankton at a permanent station off Kerguelen Islands, Southern Ocean. Polar Biol. 20, 342-351.

Leakey, R.J.G., Fenton, N., Clarke, A., 1994. The annual cycle of planktonic ciliates in nearshore waters at Signy Island, Antarctica. J. Plankton Res $16,841-856$

Louanchi, F., Ruiz-Pino, D.P., Jeandel, C., Brunet, C., Schauer, B., Masson, A., Fiala, M., Poisson, A., 2001. Dissolved inorganic carbon, alkalinity, nutrient and oxygen seasonal and interannual variations at the Antarctic Ocean JGOFS-KERFIX site. Deep-Sea Res. I 48, 1581-1603.

Lovejoy, C., Legendre, L., Klein, B., Tremblay, J.E., Ingram, R.G., Therriault, J.C., 1996. Bacterial activity during early winter mixing (Gulf of St. Lawrence, Canada). Aquat. Microb. Ecol. 10, 1-13.

Moline, M.A., Prézelin, B.B., 1996. Long-term monitoring and analyses of physical factors regulating variability in coastal Antarctic phytoplankton biomass, in situ productivity and taxonomic composition over subseasonal, seasonal and interannual time scales. Mar. Ecol. Prog. Ser 145, $143-160$.

Park, Y.H., Charriaud, E., Fieux, M., 1998. Thermohaline structure of the Antarctic surface water winter water in the Indian sector of the Southern. Ocean. J. Mar. Systems 17, 5-23.

Platt, T., Sathendranath, S., Ulloa, O., Harrison, W.G., Hoepffner, N., Goes, J., 1992. Nutrient control of phytoplankton photosynthesis in the western North Atlantic. Nature 356, 229-231.

Priddle, J., Smetacek, V., Bathmann, U., 1992. Antarctic marine production, biogeochemical carbon cycles and climatic change. Phil. Trans. R. Soc. Lond 338, 289-297.

Rivkin, R.B., 1991. Seasonal patterns of planktonic production in McMurdo Sound, Antarctica. Am. Zool 31, 5-16.

Sazhin, A.F., 1993. Bacterioplankton of surface waters in Antarctic zone of the Pacific. Russ. J. Aquat. Ecol 2, 103-109.

Smith, S.V., Mackenzie, F.T., 1987. The ocean as a net heterotrophic system: implication from the carbon biogeochemical cycle. Global Biogeochem. Cycles 1, 187-198.

Theil-Nielsen, J., Søndergaard, M., 1998. Bacterial carbon biomass calculated from biovolumes. Arch. Hydrobiol 141, 195-207.

Tréguer, P., Jacques, G., 1992. Dynamics of nutrients and phytoplankton, and fluxes of carbon, nitrogen and silicon in the Antarctic Ocean. Polar Biol 12, 149-162.

Trembley, J.E., Klein, B., Legendre, L., Rivkin, R.B., Therriault, J.C., 1997. Evaluation of $f$-ratios in oceans based on phytoplankton size structure. Limnol. Oceanogr 37, 595-601.

Trousselier, M., Bouvy, M., Courties, C., Dupuy, C., 1997. Variation of carbon content among bacterial species under starvation condition. Aquat. Microb. Ecol 13, 113-119.

Vosjan, J.H., Olanczuk-Neyman, K.M., 1991. Influence of temperature on respiratory ETS-activity of micro-organisms from Admiralty Bay, King George Island, Antarctica. Neth. J. Sea Res. 28, 221-225.

Watson, S.W., Novitsky, T.J., Quinby, H.L., Valois, F.W., 1977. Determination of bacterial number and biomass in the marine environment. Appl. Environ. Microbiol 33, 940-946.

Whitaker, T.M., 1982. Primary production of phytoplankton off Signy Island, South Orkneys, the Antarctic. Proc. R. Soc. Lond. 214, 169-189.

Zweifel, U.L., Hagström, Å., 1995. Total counts of marine bacteria include a large fraction of non-nucleotide-containing bacteria (ghosts). Appl. Environ. Microbiol 61, 2180-2185.

Wiebe, W.J., Sheldon, W.M., Pomeroy, L.R., 1993. Evidence for an enhanced substrate requirement by marine mesophilic bacterial isolates at minimal growth temperatures. Microb. Ecol 25, 151-159. 